\title{
REFERENSI KONSUMEN DALAM MENENTUKAN KEINGINAN MENGINAP BERDASARKAN SANITASI LINGKUNGAN HOTEL BERBINTANG LIMA DI KOTA SURAKARTA
}

\author{
R. INDRA GUNAWAN \\ Program Studi Teknik Lingkungan, Fakultas Teknik, Universitas Kristen Surakarta \\ Email : indra@uks.ac.id \\ ELVIS UMBU L \\ Program Studi Teknik Lingkungan, Fakultas Teknik, Universitas Kristen Surakarta \\ Email : eumbulolo@yahoo.co.id \\ GANESHA \\ Program Studi Teknik Lingkungan, Fakultas Teknik, Universitas Kristen Surakarta \\ Email : ganeshaganes6@gmail.com
}

\begin{abstract}
Abstrak
Kondisi sanitasi lingkungan yang kondusif dapat memberikan rasa nyaman yang lebih baik untuk dihuni. Akomodasi yang berada di lokasi yang strategis ternyata juga lebih dipilih oleh konsumen yang membutuhkan, terlebih jika konsumen tersebut merupakan individu yang produktif dan memiliki tingkat mobilitas yang tinggi. Lokasi tempat tinggal dengan lokasi kerja atau aktivitas lainnya yang berdekatan akan menunjang produktivitas konsumen tersebut. Kondisi sanitasi lingkungan yang bersih diduga juga menjadi salah satu bahan pertimbangan konsumen yang akan menentukan dimana mereka akan menginap. Karakteristik konsumen perlu dilakukan agar pelaku usaha dapat mengetahui bagaimana konsumen yang dituju sehingga diharapkan dapat memenuhi kebutuhan dan keinginan konsumen. Jika pelaku usaha memahami karakteristik atau profil konsumen mereka maka pelaku usaha perhotelan dapat memaksimumkan daya tariknya melalui produk dan bauran pelayanan dari sektor sanitasi lingkungannya. Penelitian ini bertujuan untuk mencari tahu apakah ada perbedaan nyata dari konsumen dalam pengambilan keputusan menentukan hotel berbintang lima yang dipilih berdasarkan sanitasi lingkungannya, sehingga pelaku usaha dapat menetapkan strategi berdasarkan hasil yang diperoleh. Analisis faktor-faktor yang mempengaruhi preferensi konsumen dilakukan sebagai gambaran yang dapat mempengaruhi kepuasan konsumen terhadap sanitasi lingkungan hotel berbintang lima di Kota Surakarta.
\end{abstract}

Kata Kunci : sanitasi, lingkungan, hotel, Kota Surakarta

\begin{abstract}
The sanitation condition that conducive bring better calmness to be occupied. The accommodation in the strategic area also become one of the best option by the needed customer, more over if they are productive individual and have high mobility. The residential that connected with the working space or other activities near with each other will support them. The
\end{abstract}


clean environment sanitation suspected as one of the customer consideration to define where they will be stayed. The customer characteristic need to define so does the business owner can better targeted the customer satisfaction. Should the business owner can manage the customer characteristic and profile, they could maximize the attraction by using product and other output. This research aimed to find out the significance of costumer preference when they choose five star hotel based on it sanitation, so they business owner can manage their strategy based on the result. The factors that impacted to the customer preference were analyzed as the description that influence customer satisfaction to the environmental sanitation of the five star hotel in Surakarta City.

Keyword : sanitation, environmental, hotel, Surakarta City

\section{PENDAHULUAN}

Preferensi mempunyai makna pilihan atau memilih. Zwarts dan Coolen (2006) menyebutkan bahwa preferensi merupakan ketertarikan relatif dari suatu fitur. Preferensi dapat berbentuk suatu penilaian dari suatu objek oleh subjek tertentu. Preferensi ini kemudian dapat menuntun seseorang dalam membuat suatu keputusan. Maka dalam hal ini, preferensi menghuni hotel berbintang lima adalah penilaian dari subjek tertentu akan faktor-faktor yang menyebabkan mereka memilih untuk menghuni sebuah akomodasi. Perkembangan kota yang cenderung semakin padat dan mempunyai eksternalitas negatif dapat membuat perbedaan preferensi memilih hunian dalam beberapa kelompok masyarakat. Zwarts dan Coolen (2006) menyebutkan bahwa beberapa kelompok subjek tertentu yang memiliki anak, lebih cenderung tinggal lebih jauh dari pusat kota dibandingkan subjek yang lebih muda dan tidak memiliki anak. Hal ini dapat dimaknai sebagai upaya masyarakat dalam memilih tempat tinggal yang lebih nyaman seiring pertambahan anggota keluarga. Dengan semakin jauhnya tempat tinggal mereka dari pusat kota, maka semakin bebas pula mereka dalam berkegiatan. Preferensi memuat parameter penilaian dimana lingkungan tempat tinggal dapat dinilai. Secara khusus, Llozor (2009) menyampaikan bahwa, parameter penilaian terhadap ruang tempat tinggal dipengaruhi oleh tiga variabel, yaitu karakteristik pengguna, atribut fisik dan kepercayaan dan persepsi terhadap ruang tersebut.

Sanitasi lingkungan adalah salah satu faktor penting yang menentukan kebersihan dan higienitas suatu tempat. Dimana sanitasi lingkungan berjalan dengan baik, maka 
dapat dipastikan bahwa suatu tempat akan menjadi higienis dan hasilnya diantaranya adalah menjadikan tempat tersebut menjadi aman bagi lingkungan baik dari segi hasil buangan limbahnya, maupun dari hasil aktivitas manusianya. Semua ini akhirnya akan menjadi jaminan bagi bumi dimana kita berpijak, dengan menjaga lingkungan tetap asri dengan pendekatan sanitasi lingkungan yang sehat dan bersih, maka akan menjadikan beban bumi ini menjadi lebih ringan (Mukono, 2004).

Undang - undang yang mengatur tentang hunian yang dijadikan hotel ataupun apartemen bisa dikatakan lengkap.

Diantaranya ada dokumen Undang Undang Nomor 28 Tahun 2002, yang mengatur tentang Bangunan Gedung. Dalam Undang Undang tersebut, pada pasal 9 ayat (1) yang berbunyi, "Persyaratan tata bangunan sebagaimana dimaksud dalam Pasal 7 ayat (3) meliputi persyaratan peruntukan dan intensitas bangunan gedung, arsitektur bangunan gedung, dan persyaratan pengendalian dampak lingkungan. Pada ayat tersebut, jelas menyebutkan bahwa setiap pemilik ataupun pengelola gedung wajib memiliki fasilitas pengendalian dampak lingkungan yang diantaranya adalah pusat sanitasi lingkungan. Undang - undang diatas diperkuat dengan terbitnya Peraturan
Menteri Pariwisata dan Ekonomi Kreatif Republik Indonesia dengan Nomor PM.53/HM.001/MPEK/2013 Tentang Standar Usaha Hotel. Pada Peraturan Menteri tersebut, pada Pasal 7 ayat (2) menyatakan bahwa, "Kelaikan fungsi bangunan gedung sebagaimana dimaksud pada ayat (1) huruf $b$, antara lain meliputi kesesuaian fungsi, persyaratan tata bangunan, keselamatan, kesehatan, kenyamanan, dan kemudahan sesuai dengan ijin mendirikan bangunan terkait”. Sedangkan di Kota Solo, peraturan yang relevan dengan pengaturan hunian adalah Peraturan Daerah Kota Surakarta Nomor 2 Tahun 2018 Tentang Penyelenggaran Izin Mendirikan Bangunan. Pada perda ini disebutkan bahwa dalam pengajuan IMB perlu memperhatikan gambar sistem utilitas yang fungsinya untuk memastikan fungsi kontrol pemerintah daerah pada bangunan tersebut.

\section{METODE PENELITIAN}

Metode penelitian dilakukan dengan menggunakan pendekatan purposive sampling (Holliday, 2002) yang dilakukan di hotel berbintang lima di Kota Surakarta dan data kemudian disusun di Universitas Kristen Surakarta dengan cara mengambil 50 responden sebagai sampel dari berbagai 
hotel berbintang lima di Kota Surakarta dalam uji lapangan. Uji sampel dilakukan dan diuji normalitas dan reliabilitasnya dimana hasilnya akan digunakan untuk menjadi bahan analisis. Data yang didapat dimasukkan ke dalam tabel dalam format excel dan dilakukan uji analisis menggunakan program SPSS versi 14 untuk dilakukan analisis descriptive dan $\mathrm{Uji} \mathrm{T}$ untuk melihat apakah ada signifikansi dari tiap perlakuan.

\section{HASIL DAN PEMBAHASAN}

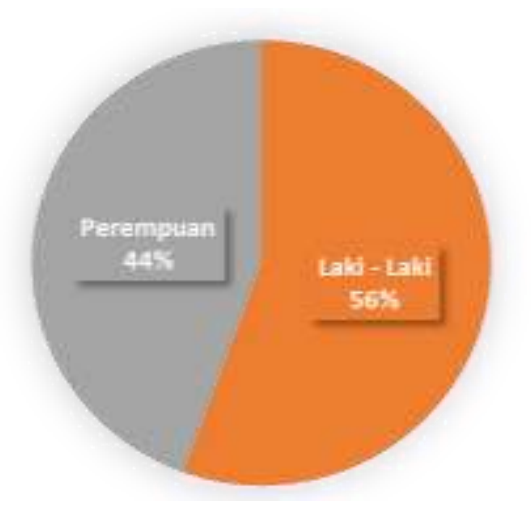

Gambar 1. Komposisi Jenis Kelamin Responden.

Pada gambar diatas, menunjukkan bahwa mayoritas responden yang menginap di Hotel Bintang 5 di Kota Solo adalah Laki laki dengan jumlah $56 \%$ dibandingkan wanita sebesar 44\%. Dari data ini dapat disimpulkan bahwa laki - laki lebih banyak melakukan perjalanan luar kota dan menginap di tempat hunian atau hotel yang memiliki fasilitas yang baik dan bersih.

Sedangkan untuk menggali informasi tentang kepuasan responden terhadap tingkat kebersihan di kamar mandi dan ruangan lain pada hotel yang ditempati, ditunjukkan pada gambar berikut ini:

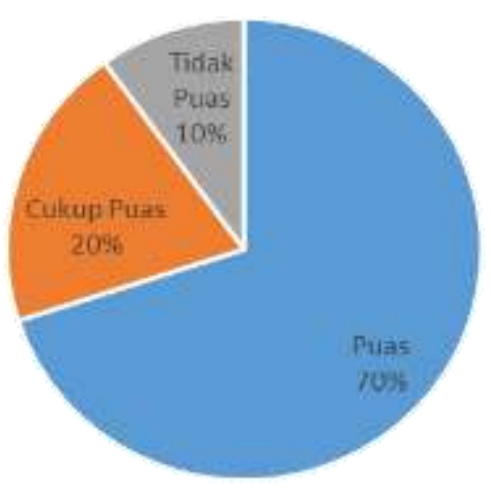

Gambar 2. Tingkat Kepuasan Responden.

Pada gambar 2 diatas, menunjukkan sebagian besar responden menyatakan puas terhadap kamar mandi dan ruangan lain yang ditempati. Hal ini ditunjukkan oleh angka kepuasan responden sebesar $70 \%$ dari sejumlah 50 responden. Kepuasan responden ini menunjukkan tingkat kebersihan, sanitasi, dan kerapian kamar mandi yang ditempati oleh responden memenuhi ekspektasi responden tersebut. Dalam hal ini, penilaian responden sejalan dengan pendapat Llozor (2009), dimana disebutkan bahwa, parameter penilaian terhadap ruang tempat tinggal dipengaruhi oleh 3 variabel, 
yaitu karakteristik pengguna, atribut fisik dan kepercayaan dan persepsi terhadap ruang tersebut.

Dalam menjawab pertanyaan mengenai tingkat preferensi responden mengenai ada bath up atau tidak, terkait kemudahan sanitasinya, ditunjukkan pada grafik dibawah ini:

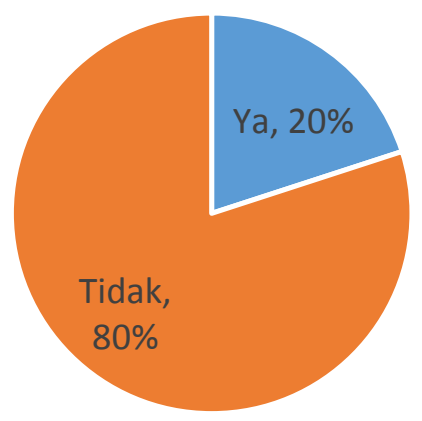

Gambar 3. Preferensi Responden Terhadap Ketersediaan Bath up.

Pada gambar 3 diatas, $80 \%$ responden menyatakan tidak membutuhkan adanya bath up di kamar mandi yang ditempati. Hal ini menunjukkan bahwa responden memiliki karakteristik penghuni yang simpel dan berwawasan lingkungan. Dimana lebih memilih menggunakan shower daripada bath up untuk penghematan air dan kepraktisan. Selain itu, hasil ini juga menunjukkan bahwa hotel yang dijadikan lokus penelitian juga memiliki wawasan lingkungan dengan mendesain ruang kamar mandi yang hemat sumber daya air, sehingga bisa disebutkan juga bahwa hunian hotel berbintang lima di Kota Solo yang menjadi lokus penelitian ini berwawasan lingkungan. Selain itu, semua responden menyatakan merasa nyaman dengan lingkungan hotel yang memiliki banyak ruang terbuka hijau yang berisi tanaman.

Sedangkan mengenai rencana responden yang akan kembali menginap di hotel yang dijadikan tempatnya, dapat dilihat pada gambar berikut ini:

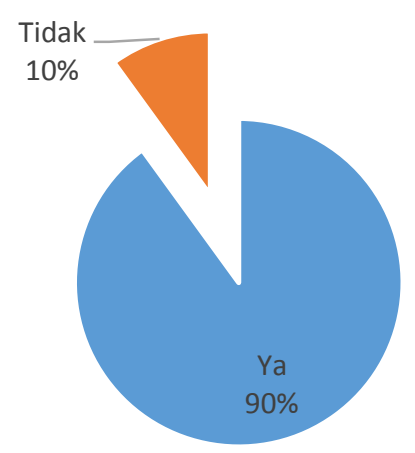

Gambar 4. Keputusan Responden Menginap Kembali.

Pada gambar 4 diatas, menunjukkan bahwa 90\% responden menyatakan akan kembali menginap di hotel yang dipilihnya. Hal ini menunjukkan karakteristik responden yang tidak mudah berpindah pilihan dan cenderung tidak mencari tempat lain untuk kesempatan menginap berikutnya. Hal ini sejalan dengan teori dari Zwarts dan Coolen (2006) yang menyebutkan bahwa preferensi merupakan ketertarikan relatif dari suatu fitur. Dimana dalam konteks penelitian ini, 
fitur yang menarik adalah tingkat kebersihan, suasana yang aman dan nyaman yang dibentuk oleh lingkungan yang memiliki ruang terbuka hijau, sanitasi lingkungan yang bersih, dan kesadaran pengelola bangunan hotel terhadap pelestarian lingkungan.

\section{KESIMPULAN}

Dalam penelitian ini, dapat disimpulkan bahwa :

1. Karakteristik konsumen hotel berbintang lima di Kota Surakarta sebagian besar adalah laki - laki dengan jumlah 56\% dibandingkan jumlah responden perempuan sebesar $44 \%$.

2. Proses pengambilan keputusan konsumen hotel berbintang lima di Kota Surakarta berdasarkan dari kepuasan terhadap rasa nyaman yang didapatkan dari kebersihan kamar mandi, sanitasi lingkungan, ruang terbuka hijau, dan wawasan lingkungan pengelola hotel.
3. Adapun faktor - faktor sanitasi lingkungan yang mempengaruhi preferensi konsumen hotel berbintang lima di Kota Surakarta adalah tingkat penggunaan air yang tidak boros dengan membatasi penggunaan bath up di kamar mandi, adanya ruang terbuka hijau di sekitar kawasan hotel, dan kebersihan sanitasi ruangan hunian.

4. Secara umum, hotel bintang lima di Kota Surakarta telah memberikan kepuasan dan rasa nyaman terhadap responden.

\section{UCAPAN TERIMA KASIH}

Penulis mengucapkan terima kasih kepada tim penelitian ini, Bp. Elvis Umbu Lolo, ST., MT dan Ganesha, selama penelitian dilaksanakan dapat bekerjasama dengan baik. Selain itu penulis juga mengucapkan terima kasih kepada pengelola dan pelanggan hotel berbintang lima di Kota Surakarta yang mengijinkan penelitian ini dilaksanakan. 


\section{DAFTAR PUSTAKA}

Holliday, A. 2002. Doing and Writing Qualitative Research. London: Sage Publications.

Llozor, Benedict D. "Identifying Preferences od Apartment Dwellers: A Case Study in Michigan, USA." International Journal of Housing Markets and Analysis Vol.2 No.3, 2009: 276-292.

Mukono. 2004. Higiene Sanitasi Hotel Dan Restoran. Pusat Penerbitan dan Percetakan Unair :Surabaya.

Peraturan Menteri Pariwisata dan Ekonomi Kreatif Republik Indonesia dengan Nomor PM.53/HM.001/MPEK/2013 Tentang Standar Usaha Hotel.

Undang Undang Nomor 28 Tahun 2002, tentang Bangunan Gedung.

Zwarts, Astrid, dan Henny Coolen. "The Meaning of Residential Environment Features: A Case Study Comparing Urban and Suburban Apartment Dwellers." Journal of Architectural and Planning Research Vol. 23 No. 3, 2006: 200-215.

Peraturan Daerah Kota Surakarta Nomor 2 Tahun 2018 Tentang Penyelenggaran Izin Mendirikan Bangunan. 